\title{
MEDITASI SEBAGAI MIND BODY MEDICINE
}

\author{
Oleh : \\ I Komang Yuni Arta \\ Institut Hindu Dharma Negeri Denpasar \\ juniarta32@,gmail.com
}

\section{ABSTRACT}

Humans are one of the tangible proofs of existence in the universe whose life holds many mysteries that are very interesting objects of curiosity. Human life which is a perfect relation of two dimensions of life, is called sekala or material world and niskala or transcendent world becomes a space of inquiry to create a balanced life physically and spiritually. The many problems experienced by humans make meditation a very powerful technique in understanding human life materially and spiritually. In various scientific studies it has been found that meditation can help a person to revitalize his life both biologically and mentally. This practice becomes moderate between a person's mind and body, which when a person's mind is in a positive or negative state, will directly affect its biological aspects. Meditation in this case acts as a mind body medicine that creates a placebo effect that is able to provide a variety of positive effects on a person's life through mechanisms that will change his perception and beliefs. Therefore, meditation as mind body medicine is a very important practice to be carried out to create a healthy mind, mental and physical for a healthy and harmonious life.

\section{Keywords: Meditation, Mind body medicine}

\begin{abstract}
ABSTRAK
Manusia adalah salah satu bukti nyata eksistensi di alam semesta yang kehidupannya menyimpan banyak misteri yang menjadi suatu objek keingintahuan yang sangat menarik. Kehidupan manusia yang merupakan relasi sempurna dari dua dimensi kehidupan yang disebut sebagai niskala atau dunia material serta niskala atau dunia transenden menjadi ruang penyelidikan demi menciptakan kehidupan yang seimbang secara jasmanai dan rohani. Banyaknya permasalahan yang dialami oleh manusia menjadikan meditasi sebagai suatu teknik yang sangat ampuh dalam memahami kehidupan manusia secara material dan spiritual. Dalam berbagai penelitian yang dilakukan secara ilmiah telah ditemukan bahwa meditasi dapat membantu seseorang dalam merevitaslisasi kehidupannya secara biologis maupun kondisi mental. Praktik ini menjadi moderat antara pikiran
\end{abstract}


dan tubuh seseorang yang mana ketika pikiran seseorang dalam keadaan yang positif ataupun negatif maka hal itu akan berdampak secara langsung terhadap aspek biologisnya. Meditasi dalam kasus tersebut berperan sebagai mind body medicine yang menciptakan efek placebo yang mampu memberikan berbagai efek positif terhadap kehidupan seseorang melalui mekanisme-mekanisme yang akan merubah persepsi dan keyakinannya. Oleh karena itu maka meditasi sebagai mind body medicine adalah sebuah praktik yang sangat penting untuk dilaksanakan demi menciptakan kesehatan pikiran, mental serta fisik demi kehidupan yang sehat dan harmonis.

\section{Kata kunci: Meditasi, Mind body medicine.}

\section{PENDAHULUAN}

Manusia merupakan bukti nyata suatu eksistensi di alam semesta ini. Dari awal terciptanya peradaban, kehidupan manusia selalu menyimpan misteri dalam kehidupannya. Manusia adalah sebuah objek keingin-tahuan yang sangat menarik dan bahkan lebih menarik dari alam sekitarnya. Pertanyaan-pertanyaan tentang kehidupan manusia akan selalu ada sepanjang peradaban ini eksis. Sebenarnya siapakah manusia itu? Dari mana datangnya? Serta apakah tujuan hidupnya? Dari generasi ke generasi, para ilmuan dengan pemikirannya yang terbatas selalu berusaha untuk memecahkan segala misteri dalam kehidupan manusia yang menyangkut tentang asal-usul dan kemana hidup ini akan dibawa setelah kematian. Sementara itu berbagai pandangan tentang manusia juga tercipta dari pemikiran filsafat. Filsafat barat misalnya, menyatakan bahwa manusia hanyalah merupakan gabungan dari pikiran dan badan (mind-body-complex). Sementara itu dalam filsafat timur (India) mengatakan bahwa manusia tiada lain adalah Atman atau jiwa.
Socrates mengatakan bahwa "yang paling mulia dari semua penyelidikan adalah studi tentang manusia dan tentang bagaimana manusia seharusnya dan apa yang ia cari" (Putra, 2014: vii). Sementara itu dalam pendapat lainnya mengatakan bahwa raja dari pengetahuan adalah pengetahuan tentang siapa sebenarnya dirimu yang sejati. Ketika manusia telah mampu melihat kedalam dirinya, kemudian ingin menyelidiki tentang hakikat diinya yang sejati maka segera ia akan terbebas dari segala keraguan tentang hidup ini sebagaimana yang diajarkan oleh Krishna kepada arjuna sebelum perang Bharata-Yuda.

Pengetahuan akan Sang diri (true self) sesungguhnya akan membawa kehidupan manusia menuju sesuatu yang mutlak dan absolut, dan tentu hal ini merupakan jawaban atas segala misteri. Akan tetapi, jauh sebelum hal itu diraih, manusia masih harus mempelajari, menganalisis serta memahami bahwa kehidupan ini merupakan kombinasi sempurna antara sekala (dunia material) dan niskala (dunia transenden). Melalui mekanisme ini menusia menjalani kehidupannya 
dalam dua dimensi dunia yang berbeda tapi saling berhubungan. Hubungan diantara kedua dimensi dunia ini sangatlah erat dan bahkan tidak dapat dipisahkan satu sama lain. Dalam dua mekanisme ini manusia harus mempelajari dirinya yang bersifat material dan juga non-material. Singh (2016: 35) mengulas tentang manusia dalam perspektif Vedanta yang memandang bahwa kehidupan tiada lain merupakan partikel spiritual dasar yang disebut sebagai atman, jiwa atau spiriton. Dalam paradigma Vedanta, sistem biologis manusia bisa dirasakan sebagai perwujudan dari badan-badan spiritual, badan halus serta badan kasar dengan partikel rohani, yaitu spiriton di dalamnya.

Melalui pemahaman yang dibangun diatas paradigma-paradigma tentang kehidupan, manusia pada akhirnya harus menjalani kehidupannya diatas kesadaran jasmani dan rohani. Kehidupan jasmani akan selalu mendukung terhadap apa yang dijalani dalam tataran rohani begitu pula sebaliknya. Kesadaran selalu menjadi kunci utama dalam segala hal. Ketika manusia sadar bahwa ia adalah jiwa maka ia harus bertindak sebagai jiwa semesta dan hidup dalam ke-universalan. Sementara itu, ketika manusia sadar bahwa ia tersusun atas pola-pola kehidupan jasmani maka ia harus selalu menjaganya karena itu merupakan asetnya dalam kehidupan ini. Kehidupan ini tidak akan bisa terlepas dari badan jasmani meskipun kita telah sadar bahwa ada sesuatu yang jauh lebih sempurna dari sekedar badan, akan tetapi tanpa badan ini kehidupan sebagai manusia tidaklah pernah ada. Hal ini mungkin senada dengan sistem filsafat barat yang memandang bahwa hidup merupakan kombinasi anatara pikiran dan badan (mind-body-complex).
Pikiran merupakan satu bagian dari kehidupan yang dapat dikatakan sebagai pusat pengendalian kehidupan jasmani. Akan tetapi, dalam pandangan spiritual (upanishad) mengatakan bahwa pikiran merupakan maya adanya, ia adalah ilusi tempat dimana baik dan buruk berada, tempat dimana dualitas tercipta, itulah pikiran disebut sebagai manomaya kosha. Pikiran dan tubuh jasmani bukanlah dua hal yang terpisah melainkan adalah satu kesatuan yang saling mendukung dan mempengaruhi. Keduanya merupakan kombinasi maya yang keberadaannya adalah palsu namun ketika manusia menjalani kehidupan jasmaninya tetaplah keduanya menajadi sangat penting. Gunawan (2018: 19) mengatakan bahwa tidak ada pemisahan antara tubuh dan pikiran. Apa yang terjadi pada pikiran dan apa yang terjadi pada tubuh saling terkait dan mempengaruhi. Keterkaitan ini sebenarnya sangat mudah untuk diarasakan, ketika kita merasa cemas dan khawatir terhadap suatu hal maka kita merasakan perut kita menjadi mulas, sakit kepala, dan mudah mengalami kecelakaan. Sementara ketika kita dalam keadaan bahagia, maka tubuh kita terasa penuh energi, ringan dan nyaman.

Ketika pikiran dan badan kita terkoneksi secara langsung maka penting bagi manusia untuk memahami kinerja pikirannya. Dalam studi ilmiah, pikiran adalah penerima sinyal dan mengolahnya menjadi sesuatu yang positif dan negatif. Ketika pikiran mengolah suatu informasi secara negatif maka dapaknya terhadap tubuh juga berujung negatif. Akan tetapi, sebaliknya jika informasi itu diolah menjadi energi positif maka haslinya adalah sesuatu yang baik bagi tubuh. Oleh sebabnya 
sangatlah perlu untuk mengkondisikan pikiran dalam keadaan rileks, seimbang dan harmoni. Untuk mendapatkan hal tersebut perlulah suatu metode-metode khusus seperti meditasi.

Meditasi dalam era modern ini menjadi salah satu metode praktis yang berlaku sebagai moderat antara tubuh dan pikiran. Meditasi menjadi obat bagi pikiran dan tubuh fisik manusia yang mampu membantu seseorang dalam menjaga kesehatannya, sehingga meditasi ini merupakan obat bagi pikiran serta tubuh manusia atau disebut sebagai mind bodymedicine. Meditasi sebagai mind body medicine bekerja melalui manfaat-manfaat positif dan ditimbulkan dari praktik meditasi baik secara jasmani maupun rohani. banyak penelitian ilmiah menunjukan hasil bahwa meditasi mampu memperbaiki kinerja pikiran seseorang serta persepsinya terhadap hidup termasuk keyakinan yang dimilikinya. Dalam istilah kesehatan pikiranpikiran positif, keyakinan-keyakinan positif serta persepsi-persepsi yang positif yang timbul dari praktik meditasi ini disebut sebagai efek plasebo (placebo effect). Plasebo dikatakan sebagai dokter dalam diri dimana hal ini dipengaruhi oleh keadaan pikiran yang positif serta keyakinan yang tumbuh dalam diri. Sebagaimana dokter pada umumnya yang bertugas untuk menjaga dan menyembuhkan seorang pasien, maka sama halnya dengan pikirnpikiran positif dan keyakinan yang bertugas sebagai penyembuh dan penjaga kesehatan badan jasmani yang akan mempengaruhi keadaan mental serta spiritual manusia.

Dengan melihat bahwa meditasi merupakan satu metode praktis dalam revitalisasi diri dan kesehatan manusia, maka tulisan ini ingin membahas lebih dalam bagaimana sesungguhnya meditasi bekerja terhadap kehidupan manusia secara jasmani dan rohani. bagaimana meditasi menimbulkan efek plasebo yang merupakan obat penyembuh bagi pikiran serta tubuh manusia (mind-body-medicine) dikarenakan kehidupan manusia di jaman ini diliputi oleh banyak Penyakitpenyakit yang secara langsung membawa penderitaan secara fisik dan mental bagi manusia. Sehingga, meditasi bisa menjadi salah satu jalan untuk melepaskan segala penderitaan yang dialami manusia secara fisik, mental dan spiritual.

\section{PEMBAHASAN}

\subsection{Psikosomatis dan Plasebo Efek}

Psikosomatis adalah istilah yang digunakan sebagai kondisi dimana pikiran mampu mempengaruhi kinerja tubuh manusia secara fisik. (Gunawan, 2018: 49) menjelaskan bahwa psikosomatis sendiri berasal dari kata psychosomatic, terdiri dari dua kata yaitu psyche yang artinya kehidupan dan dalam terjemahan bebasnya adalah jiwa atau pikiran, serta somato atau soma yang artinya tubuh. Dengan demikian psychosomatic atau psikosomatis adalah kondisi dimana pikiran manusia mempengaruhi tubuh.

Kondisi psikosomatis ini bersifat netral, diamana ia bisa bersifat positif ataupun negatif tergantung bentuk pikiran yang dihasilkan. Pikiran positif mampu memberikan dampak positif bagi fisik manusia dan pikiran negatifnya akan bekerja secara negatif terhadap tubuhnya. Hal ini terjadi berdasarkan hukum konsekuensi yang memang tak dapat dihindari. Dalam istilah biologi, dampak positif yang dihasilkan dari 
pikiran manusia disebut sebagai efek plasebo dan sebaliknya dampak negatif yang dihasilkan oleh pikiran disebut sebagai efek nosebo. Kita tentunya sering mendengar istilah mens sana in corpora sano yang artinya adalah "didalam tubuh yang sehat terdapat jiwa yang kuat". Dampak-dampak positif yang dihasilkan dari pikiran yang positif yang mampu mengasilkan tubuh yang sehat bagi manusia tentunya akan berdapak pada kehidupan jangka panjang manusia. Jiwa yang kuat tentunya diterjemahkan dari spirit kehidupan yang selalu ada dimana hal itu dipadukan dari kesehatan pikiran serta tubuh manusia.

Efek plasebo adalah efek sugesti atau keyakinan yang membuat kondisi seorang pasien membaik ketika mengkonsumsi obat yang tidak mengandung unsur penyembuh apapun dengan yakin (Lipton, 2019: 245). Senada dengan pernyataan tersebut, Norman Cousin dengan jelas mengatakan bahwa plasebo adalah dokter yang ada di dalam diri (The placebo is the doctor who resides whitin). Hingga saaat ini telah banyak dilakukan penelitian tentang efek placebo ini dan kebanyakan dari penelitian mereka menyetujui bahwa efek plasebo terjadi karena tiga faktor utama yaitu:

1. Keinginan untuk sembuh.

2. Pengharapan bahwa mereka akan disembuhkan, atau bahwa sesuatu yang positif dan baik akan terjadi.

3. Keyakinan bahwa mereka akan disembuhkan, baik karena mereka percaya pada obat yang digunakan atau karena mereka percaya pada keahlian dokter yang merawat mereka (Gunawan, 2018: 15).
Tahun 2002, sebuah studi yang dipublikasikan di American Journal of Psychiatry melaporkan bahwa $38 \%$ penderita depresi melaporkan perubahan mood positif yang bertahan lebih lama setelah diberikan obat yang sebenarnya adalah tablet biasa. Sedangkan dari riset yang dilakukan oleh Beecher seorang dokter tentara amerika serikat pada masa perang dunia I serta penelitan lainnya mengungkapkan bahwa pengobatan mempunyai efek plasebo sebesar $35 \%$, yang berarti bahwa pikiran positif dan pengharapan memiliki kontribusi kesembuhan hingga 35\% (Gunawan, 2018: 13).

Hidup manusia adalah sebuah refleksi dari keadaan pikiran, emosi serta keyakinannya. Persepi serta keyakinan manusia terhadap dunia serta kehidupannya menjadi penyebab dari segala akibat yang tampak pada setiap jengkal kehidupan manuisa. Jika kita melihat dunia sebagai cinta serta menganggapnya sangat indah dan penuh dengan kebahagiaan maka dapat dipastikan hidup kita akan diliputi oleh rasa syukur dan kebahagiaan. Sebaliknya, jika kita melihat dunia ini sebagai sesuatu yang jahat, buruk dan penuh dengan penderitaan maka sudah dapat dipastikan bahwa hidup kita akan menderita sepanjang umur. Hal ini menandakan bahwa apapun yang kita yakini terhadap suatu hal akan berdampak pada kondisi mental dan psikologis kita.

Mahatma Gandhi penah mengatakan bahwa keyakinan kita akan menjadi pikiran kita; pikiran kita akan menjadi kata-kata kita; katakata kita akan menjadi tindakan kita; tindakan kita akan menjadi kebiasaan kita; kebiasaan kita akan menjadi nilai-nilai kita; nilai-nilai kita akan 
menjadi takdir kita (Lipton, 2019: 258). Apa yang diungkapkan oleh Mahatma Gandhi mengungkap sebuah rahasia kehidupan kita yang ditentukan dari keyakinan serta pikiran kita. Bagaimana kita meyakini kehidupan ini akan menjadi sebuah takdir bagi kita sendiri. Oleh sebab itu penting bagi kita untuk selalu mengawasi keadaan pikiran kita dikarenakan fungsi pikiran ialah sebagai jembatan antara keyakinan serta kenyataan dalam hidup kita. Lipton (2019: 259-260) juga mengatakan bahwa ketika kita mengubah cara pandang kita terhadap dunia serta yakin ketika kita mengubah keyakinan kita, kita mengubah komposisi neurokimia darah, yang kemudian memicu perubahan komplementer di dalam sel-sel tubuh. Selain itu, persepsi dari pikiran positif mampu meningkatkan kesehatan melalui peningkatan fungsi imun. Sementara itu, fungsi imun yang terhambat oleh persepsipersepsi negatif dapat memicu timbulnya berbagai penyakit. Persepsi negatifjuga dapat menimbulkan stress psikologis kronis yang melemahkan dan menyebabkan pengaruh negatif pada fungsi gen.

Bagaimana besarnya pengaruh pikiran terhadap sistematika biologis manusia sepatutnya diketahui oleh setiap orang yang hendak merubah kondisi kesehatannya. Menjaga gelombang positif dalam pikiran menjadi kunci utama untuk mencegah ataukah menanggulangi Penyakit psikosomatis yang ditimbulkan.

\subsection{Meditasi dan Pikiran}

Meditasi menjadi sebuah metode yang banyak dipraktikan guna merevitalisasi kehidupan seseorang dalam aspek biologisnya maupun kehidupan spiritualnya. Perkembangan ajaran meditasi di era saat ini menjadi sangat pesat dan sangat popular, dikarenakan manfaat yang dihasilkan sangatlah luar biasa bagi kehidupan manusia. Vaisvanathan (2001: 173) menjelaskan bahwa kata meditasi berasal dari bahasa latin yaitu dari kata Meditari dan akar kata mederi yang berarti menyembuhkan yang menyangkut penyembuhan mental dan psikis. Sedangkan Sivananda (2008: 52) menjelaskan bahwa meditasi adalah suatu keadaan diamana tiadanya keinginan atau pikiran sensual. Meditasi adalah membangkitkan gelombang dan menjaga gelombang kesadaran Tuhan.

Meditasi adalah sebuah metode praktis kehidupan yang mampu menjangkau dua dimensi kehidupan manusia yaitu dimensi material sekaligus dimensi spiritual. Apa yang diungkapkan oleh Vaisvanathan serta Sivananda tentang meditasi menjelaskan bahwa baik kehidupan material dan spiritual manusia hendaknya dalam keadaan seimbang. Dalam satu sisi, meditasi bertujuan untuk menyembuhkan manusia dari Penyakit mental dan psikis, dilain sisi meditasi juga bertujuan untuk mengembangkan kesadaran Tuhan dalam diri manusia sehingga ia mempu terbebas dari segala jenis penderitaan mental dan juga fisik. Ada keterkaitan yang sangat segnifikan antara dua dimensi kehidupan manusia yang dikenal dalam sebutan sekala dan niskala atau dunia material dan dunia transendental. Ketika manusia hidup dalam keseimbangan ini maka niscaya kebahagiaan diraihnya.

Sivananda (2001: 56) menerangkan bahwa meditasi adalah sebuah ramuan yang kuat yang berguna bagi syaraf serta setiap sel dalam tubuh 
manuisa. Ketika getaran suci merasuk ke dalam seluruh sel dalam tubuh maka setiap Penyakit akan disembuhkan. Kekuatan menenangkan muncul selama latihan meditasi. Meditasi akan mempengaruhi syaraf, pikiran, sel, dan organ dalam tubuh serta energi spiritual akan mengalir di dalam tubuh sadhaka (pelaku spiritual).

Fakta bahwa manfaat meditasi dapat dijangkau melalui metode ilmiah perlahan mampu membawa kesadaran umat manusia akan pentingnya bermeditasi untuk merawat gelombang kehidupan. Banyak penelitian-penelitian ilmiah yang mampu mengungkapkan bagaimana dampak meditasi terhadap otak serta gelombang pikiran manusia yang nantinya akan terefleksi melalui kondisi fisik serta mental manusia.

Meditasi yang sering diasosiasikan dengan pikiran manusia menjadi salah satu mindfulness teknik yang bertujuan untuk mendapatkan keseimbangan jasmani dan rohaninya. Yoga sutra patanjali sejak dahulu kala telah menyuratkan tentang gelombang pikiran yang disebut sebgai "vrtti" adalah sebagai penyebab dari segala penderitaan manusia. Dalam sutranya disebutkan bahwa "Yogas citta vrtti nirodah" yang artinya kuirang lebih menyatakan bahwa yoga adalah pengendalian terhadap gelombang pikiran dengan segala modifikasinya. Pikiran manusia bersifat kreatif dan imajinatif sehingga ia menghasilkan banyak bentuk-bentuk pikiran yang menyebabkan segala penderitaan bagi fisik serta mental manusia. Melalui pelaksanaan yoga khususnya meditasi (dhyana dalam istilah yoga) maka manusia akan mampu mengkondisikan pikirannya secara bertahap.
Manusia berpikir sebanyak 60-7- ribu kali dalam sehari dan pikiran itu biasanya selalu diulang dalam kesehariannya sehingga secara tidak langsung ia menciptakan kondisi-kondisi yang serupa dalam hidupnya. Cara kerja pikiran dan dampaknya terhadap fisik dan psikologis manusia akan cenderung sama dikarenakan ketika 60-70 ribu pikiran sebelumnya diulang dikemudian hari, maka ia akan mengahasilkan pilihan yang sama, ketika pilihan yang sama menghasilkan tindakan yang sama maka ia akan menghasilkan pengelaman yang sama pula, dari pengalaman yang sama maka akan menghasilkan emosi yang sama juga dan begitu seterusnya. Cara kerja pikiran yang demikian tentunya tidak akan merubah hidup manusia menuju sesuatu yang lebih baik, dan bahkan jika ternyata manusia cenderung berpikir negatif maka ia mengulangi setiap pikiran negatif setiap harinya sehingga akan menimbulkan lebih banyak efek nosebo dalam hidupnya.

Pikiran merupakan sebuah getaran, sehingga jika seseorang mengulangi pikirannya secara konsisten maka ia akan mengulangi getaran pikiran yang serupa. Bila suatu materi bergetar sekali saja maka ia akan lebih mudah digetarkan dengan cara yang sama dari pada dengan cara yang baru. Sehingga semakin sering seseorang mengulangi getaran pikirannya maka akan jauh lebih mudah untuk digetarkan kembali. Setelah digetarkan berulang-ulang kali maka akan timbul kecenderungan dalam zat badan mental yang dengan otomatis mengulangi getarannya sendiri Anadas (2007: 25). Ketika pikiran yang sama bergetar setiap saat maka bisa dibayangkan 
bagaimana seseorang bisa ahli dalam satu bidang tertentu, hal itu dikarenakan ia mengulangi setiap getaran yang sama pada otaknya. Itulah sebabnya ada ungkapan yang menyatakan bahwa "Engkau adalah apa yang kau pikirkan". Melalui praktik meditasi maka kita sebenarnya melatih getaran pikiran untuk selalu dalam keadaan yang positif sehingga mengahsilkan efek placebo yang lebih banyak.

\subsection{Meditasi dan Gelombang otak (Brain waves)}

Sebuah penelitian yang dilakukan di Jerman yang melibatkan 300 peserta ke dalam program meditasi selama Sembilan bulan dengan membagi pesertanya ke dalam tiga kelompok melakukan meditasi dengan cara yang berbedabeda. Percobaan ini terdiri dari tiga periode. Masing-masing berlangsung selama tiga bulan di mana peserta menjalani tiga jenis meditasi berbeda. Jenis pertama fokus pada kesadaran (mindfulness meditation), kedua belas kasih, dan yang ketiga adalah kemampuan kognitif. Dari situ, para peneliti kemudian mengukur dan memantau otak para peserta dengan mesin MRI pada awal percobaan dan setiap selesai periode tiga bulan.

Salah satu kelompok yang melakukan meditasi kesadaran melakukan meditasi selama 30 menit setiap hari selama enam hari. Pada akhir periode tiga bulan, para peserta dalam kelompok ini menunjukkan penebalan di korteks prefrontal otak. Bagian otak tersebut merupakan area yang terlibat dalam proses penalaran yang rumit, pengambilan keputusan, dan kewaspadaan.
Kemudian kelompok tersebut beralih ke jenis meditasi yang menitikberatkan pengembangan belas kasih dan empati pada orang lain. Seperti pada sesi pertama, para peneliti mengamati perubahan dalam otak peserta setelah sesi meditasi berakhir. Kelompok ini mengalami perubahan pada daerah otak yang penting untuk pengaturan emosional. Tidak hanya otak peserta yang mengalami perubahan. Tim peneliti juga menemukan perubahan pada perilaku peserta, sesuai dengan perubahan otak mereka (https:// hellosehat.com/hidup-sehat/tips-sehat/cara-

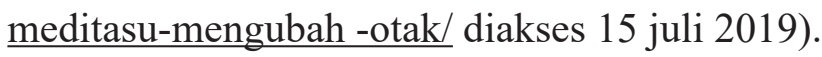

Tidak hanya itu, pada penelitian lain juga menerangkan bahwa ada perubahan dan penurunan gelombang beta pada otak ketika seseorang bermeditasi yang mana hal ini berdampak pada kemampuan otak dalam mengolah informasi.

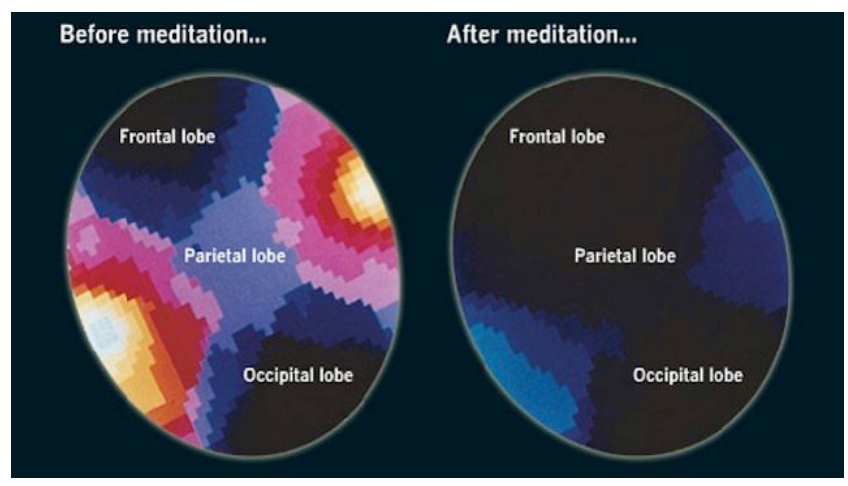

Gambar 1. Hasil scan fMRI terhadap otak seseorang dalam bermeditasi.

Gambar di atas menunjukan bagaimana gambaran otak manusia sebelum dan sesudah melakukan praktik meditasi. Bagian otak yang menunjukan warna pada bagian samping adalah 
aktivitas gelombang beta seseorang, dimana ketika seseorang bermeditasi gelombang ini tampak berkurang dan bahkan tiada. Lobus depan adalah bagian otak yang paling berkembang yang fungsinya adalah memberi pertimbangan, perencanaan, emosi, dan kesadaran diri. Selama meditasi, lobus depan cenderung offline. Lobus parietal adalah bagian otak yang memproses informasi sensorik tentang kondisi sekitar kita, membuat kita mengenali ruang dan waktu. Selama meditasi, aktivitas di lobus parietal melambat. Sementara itu Thalamus sebagai penjaga indera, organ ini memfokuskan perhatian kita dengan menyalurkan data sensorik lebih dalam ke otak dan menghentikan sinyal lain di jalurnya. Meditasi mengurangi arus informasi yang masuk hingga minimal. Formasi reticular sebagai penjaga otak, bagian ini menerima stimulus yang masuk dan menjadikan otak waspada, siap untuk memberi respon. Meditasi memanggil kembali sinyal yang kuat (http://buddhazine.com/inilah-yang-terjadipada-otak-saat-meditasi-dan manfaatnya/ Diakses 15 Juli 2019).

Meditasi dalam upayanya untuk menciptakan keyakinan-keyakinan yang positif dilakukan berdasarkan mekanisme-mekanisme tertentu. Pikiran yang berbentuk gelombang elektromagnetis dilatih selama meditasi untuk memasuki gelombang-gelombang tertentu. Dalam penyelidikan ilmiah ditemukan bahwa gelombang pikiran dibagi kedalam empat jenis, dimana menurut Singh dalam Donder (2005: 202) menampilkanya dalam bentuk table seperti berikut.
Tabel 1. Nilai EEG Patterns in Various Mental State

\begin{tabular}{|c|c|c|c|}
\hline No & Waves & Frequency & Mental State \\
\hline 1 & Beta & $14 \mathrm{~Hz}-30 \mathrm{~Hz}$ & Wakefull \\
\hline 2 & Alpha & $8 \mathrm{~Hz}-13 \mathrm{~Hz}$ & Restfull \\
\hline 3 & Theta & $4 \mathrm{~Hz}-7 \mathrm{~Hz}$ & $\begin{array}{c}\text {-Superralert } \\
\text {-Disappointment \& } \\
\text { Frustatsion }\end{array}$ \\
\hline 4 & Delta & $0,5 \mathrm{~Hz}-3 \mathrm{~Hz}$ & Deep Sleep \\
\hline
\end{tabular}

Meditasi akan membawa seseorang untuk memasuki kondisi meditative dimana gelombang pikiran manusia menurun sehingga ia mencapai ketenangan dalam pikiran. Semakin rendah gelombang pikiran seseorang maka ia semakin memasuki keadaan yang tenang. Kondisi alpa adalah kondisi dimana seseorang dalam keadaan sadar terjaga dengan segala aktivitasnya sehingga gelombang otaknya cenderung aktif dengan getarannya yang mencapai $30 \mathrm{~Hz}$. Saat seseorang bermeditasi maka secara otomatis gelombang otak seseorang akan menurun kedalam kondisi beta dimana gelombang pikiran ini bersifat tenang dan sering dimanfaatkan untuk melakukan hypnosis serta afirmasi-afirmasi positif yang mampu dibawa ke alam bawah sadarnya, dimana hal ini adalah langkah untuk memprogram ulang alam bawah sadar kita. Kondisi-kondisi dibawah gelombang beta terjadi setelah seseorang mencapai alam mimpi dan tidur lelap dimana aktivitas pikirannya sangatlah sedikit.

Sifat pikiran manusia sesungguhnya adalah mengalir secara alamiah yang disebut dengan istilah Default Mode Network (DMN). DMN ini cenderung berasal dari pengalamanpengalaman hidup yang terhimpun di alam bawah 
sadar manusia sebagai sebuah memori yang ketika kita tidak sadar maka semua memori ini akan berputar secara otomatis dan ini disebut sebagai DMN proses. Persepsi yang menganggap bahwa saat kita meditasi kita harus memfokuskan serta mengosongkan pikiran adalah sesuatu yang keliru. Pikiran manusia dalah alat perekam sekaligus pemutar film sehingga untuk menghentikan perputaran film tersebut kita harus pergi ke tenpat dimana film tersebut diputar. Tempatnya adalah di alam bawah sadar manusia. Ketika seseorang bermeditasi maka ia sesungguhnya dalam perjalanan kesana untuk menciptakan ketenangan dalam hidupnya. Kondisi meditative ini adalah kondisi di sini dan sekarang atau kondisi tanpa waktu karena yang ada hanyalah saat ini (present moment). Saat itulah seseorang memasuki kondisi seimbang dan kedamaian dalam pikiran.

\subsection{Meditasi Sebagai Mind body medicine}

Meditasi yang berkembang di era modern ini telah mampu menyadarkan banyak manusia tentang kehidupannya yang begitu kompleks. Manusia yang tersusun oleh susunan saraf, sel serta organ yang begitu kompleks mampu dipelajarti secara sistematis oleh ilmuan-ilmuan modern. Sadar akan banyaknya masalah yang terjadi pada sistem kehidupan biologis serta psikologis manusia maka secara perlahan praktik meditasi akhirnya diterima sebagai salah satu solusi terhadap masalah kesehatan manusia. Pandangan filsafat barat yang menganggap manusia sebagai mind-body-complex tentunya sejalan dengan apa yang dikandung dalam ajaran meditasi yang pada dasarnya bekerja secara sempurna dalam dua dimensi kehidupan manusia (sekala-nisakala). Meditasi sesuai dengan pandangan filsafat barat menjadi mind-body medicine atau sebuah obat yang mampu mengatasi permasalahan pikiran dan body (tubuh) manusia.

Mind body medicine terdiri dari tiga kata yaitu,. Mind (pikiran), body (tubuh), dan medicine (ilmu mengobati atau mendiagnosis). Gunawan (2018: 22-23) mendifinisikan mind body medicine dalam dua pengertian yang serupa yaitu:

1. Definisi yang diambil dari The National Institute of Health (NIH) yang menyatakan bahwa mind body medicine lebih berfokus kepada interaksi antara otak, pikiran, tubuh, dan prilaku, serta cara yang luar bisa dimana faktor emosi, kondisi mental, sosial, spiritual, dan prilaku dapat mempengaruhiu kesehatan.

2. Mind body medicine adalah studi mengenai bagaimana aktivitas mental (kepercayaan/belief) mempengaruhi kesehatan dan bagaimana dengan menggunakan intervensi mental dapat mengubah konten aktivitas-aktivitas mental ini, baik dengan mengurangi stress atau mempengaruhi kognisi atau emosi untuk meningkatklan kesehatan.

Tubuh serta pikiran manusia adalah satu kesatuan yang saling mempengaruhi. Istilah psikosomatis digunakan untuk menerangkan bagaimana pengaruh pikiran terhadap tubuh sedangkan ketika tubuh berpengaruh terhadap 
pikiran disebut sebagai somatopsikis contohnya ketika seeorang menerima pijatan. Antara meditasi-pikiran-tubuh menjadi sebuah hubungan yang pararel yang saling berketerkaitan dalam kehidupan manusia yang mampu menentukan nasib manusia serta kesehatannya.

Sebuah penelitian mengungkapkan bahwa hanya dengan delapan jam melakukan meditasi kesadaran (mindfull meditation) sudah cukup segnifikan untuk mengubah fungsi-fungsi gen vital. Dibandingkan dengan kelompok kontrol, para meditator menunjukan perbedaan spectrum genetic dan molekuler yang meliputi penurunan level gen pro-inflamasi dan mengubah level sistem mekanik yang mengatur gen (generegulating machinery). Perubahan ekspresiekpresi gen yang dapat diamati ini juga terkait dengan lebih cepatnya fase pemulihan dari situasi yang menimbulkan stress dan membuktikan bahwa praktik meditasi kesadaran (mindfull meditation) dapat mendukung kesehatan karena terjadinya perubahan genom (Kaliman \& Lopez dalam Lipton, 2019: 267)

Bagaimana praktik meditasi mampu mengubah dan memperbaiki kesehatan manusia melalui perbaikan serta perubahan fungsi gen dan juga meredam kondisi stress membuktikan bahwa praktik ini memiliki efek plasebo yang cukup segnifikan sehingga ia mampu menjadi sebuah mind body medicine bagi para meditator. Bukti bahwa keyakinan memiliki pengaruh yang sangat kuat terhadap fisiologi, ekspresi gen, dan prilaku membuat ahli epigenitika Cole menyimpulkan bahwa "sampai batas tertentu yang jarang dihargai para ahli imunologi dan psikoilog, kita adalah arsitek dari pengalaman kita sendiri. Pengalaman subjektif anda memiliki kekuatan yang lebih besar dari pada situasi objektif anda" (David dalam Lipton, 2019: 272). Dalam pendapat Cole tersebut istilah pengalaman subjektif sesungguhnya mewakili setiap keyakinan serta persepsi kita terhadap sesuatu, sedangkan istilah objektif tentunya merupakan realitas kita. Sehingga, apa yang kita yakini dan kita miliki sebagai persepsi jauh lebih kuat dibandingkan apa yang menjadi realitas kita saat ini.

\section{SIMPULAN}

Meditasi sebagai sebuah teknik mampu memberikan berbagai efek positif terhadap seseorang yang disebut sebagai efek plasebo. Efek plasebo ini bekerja melalui perubahan-perubahan pada persepsi serta keyakinan seseorang. Ketika seseorang melakukan praktik meditasi maka ia akan memasuki kondisi gelombang otak yang lebih rileks, santai dan tenang sehingga sekaligus ia mampu memprogram ulang alam bawah sadarnya. Ketika alam bawah sadar seseorang diprogram melalui meditasi maka disana akan terjadi peubahan-perubahan pada DMN (Default Mode Network) serta pola pikir seseorang yang mempengaruhi persepsi dan keyakinan terhadap kehidupannya. Ketika seseorang merubah cara pandang serta keyakinannya maka hal tersebut juga akan berdampak kepada sistem biologisnya sehingga apa yang dipikirkannya akan tampak pada kehidupan fisiknya. Pikiran yang mempengaruhi tubuh seseorang disebut sebagai psikosomatis dimana psikosomatis ini bersifat netral dalam 
artian ketika pikiran negatif menimbulkan dampak negartif sebaliknya pikiran positif akan berdampak positif pula. Melalui praktik meditasi maka seseorang akan lebih mampu untuk melihat kehidupannya sebagai hal yang positif sehingga dalam hal ini maka meditasi menjadi moderat positif antara pikiran serta tubuh manusia yang dikenal dengan istial mind body medicine.

\section{DAFTAR PUSTAKA}

Anadas, Ra. 2007. Meningkatkan Kesadaran Diri Sejati Atman Menuju Kebahagiaan dan Moksa. Surabaya: Paramita.

Donder, I Ketut. 2005. Esensi Bunyi Gamelan Dalam Prosesi Ritual Hindu Perspektif Filosofis,-Teologis, Psikologis, Sosiologis, dan Sains. Surabaya: Paramita.

Gunawan, Adi W. 2018. The Miracle Of Mind Body Medicine: How To Use Your Mind For Better Health. Jakarta: Gramedia.

Lipton, Bruce. 2019. The Biology of Belief: Misteri Pikiran, Keyakinan, Sel, dan

DNA. Banten: Javanica PT Kaurama Buana Antara.

Putra, Ngakan Putu. 2014. Kamu Adalah Tuhan: Manusia dalam Agama Hindu. Jakarta: Media Hindu.

Singh, T.D. 2016. Vedanta \& Sains tentang Fenomena penuaan. Denpasar : PT. Temprina Media Grafik Bali.
Sivananda, Sri Swami. 2008. Konsentrasi Dan Meditasi Uraian Tentang Energi Yang Terdapat Dalam Diri Dan Aplikasinya Dalam Kehidupan Sehari- Hari. Surabaya: Paramita.

Visvanathan, Ed. 2001. Tanya Jawab Hindu Bagi Pemula. Surabaya: Paramita.

(https://hellosehat.com/hidup-sehat/tips-sehat/ cara-meditasu-mengubah-otak/ diakses 15 juli 2019).

(http://buddhazine.com/inilah-yang-terjadipada-otak-saat-meditasi-dan manfaatnya/ Diakses 15 Juli 2019). 